\title{
The stimulus-sensitive $\mathrm{H}_{2} \mathrm{O}_{2}$-generating system present in human fat-cell plasma membranes is multireceptor-linked and under antagonistic control by hormones and cytokines
}

\author{
Heidemarie I. KRIEGER-BRAUER and Horst KATHER \\ Klinisches Institut für Herzinfarktforschung an der Medizinischen Universitätsklinik, Bergheimerstrasse 58, 69115 Heidelberg, Germany
}

Previous work demonstrated that human fat-cells possess a plasma-membrane-bound $\mathrm{H}_{2} \mathrm{O}_{2}$-generating system that is activated by insulin. Here we show that this system is under antagonistic control by various hormones and cytokines that typically act through several distinct receptor families. Similarly to insulin, oxytocin and tumour necrosis factor $\alpha$ acted as stimulators of NADPH-dependent $\mathrm{H}_{2} \mathrm{O}_{2}$ generation, whereas isoprenaline, a $\beta$-adrenergic agonist, had inhibitory effects. Surprisingly, the acidic and basic isoforms of fibroblast growth factor as well as homodimeric platelet-derived growth factor AA and BB had antagonistic stimulatory and inhibitory effects on NADPH-dependent $\mathrm{H}_{2} \mathrm{O}_{2}$ generation. The agents tested acted at discrete ligand-specific receptors and their mechanisms of action were membrane-delimited and occurred in the absence of ATP. These findings implied that established pathways of signal transduction, including receptor kinases or second-messengerdependent protein kinases $\mathrm{A}$ and $\mathrm{C}$, were not involved and placed the stimulus-sensitive $\mathrm{H}_{2} \mathrm{O}_{2}$-generating system in a position comparable with adenylate cyclase. It was concluded that the stimulus-sensitive $\mathrm{H}_{2} \mathrm{O}_{2}$-generating system of human fat-cells meets all criteria of a universal signal-transducing system for hormones and cytokines that may link ligand binding to cellsurface receptors to changes in the intracellular redox equilibrium.

\section{INTRODUCTION}

$\mathrm{H}_{2} \mathrm{O}_{2}$ and other species that it can generate, such as hydroxyl radical and superoxide, possess significant capacity for cellular damage and have been implicated in both the aging process and the pathogenesis of chronic diseases, including atherosclerosis and cancer [1]. However, at non-cytotoxic concentrations, the response to oxidative stress is similar to the growth-stimulatory response induced by hormones and cytokines [2,3]. Indeed, redox control appears to be a broad regulatory system that could allow cells to adapt to a variety of redox-active stimuli, including u.v. radiation, ionizing radiation, alkylating agents and antitumour quinones, and appears also to be involved in signalling by hormones and cytokines [4-10].

As pointed out in a previous publication [5], $\mathrm{H}_{2} \mathrm{O}_{2}$ has long been implicated in the action of insulin and other hormones exerting insulin-like metabolic effects [6-10]. Recent evidence indicates that an increase in the production of reactive oxygen species can be elicited by many hormones and cytokines, such as thyrothropin, parathyroid hormone, interleukin $1 \alpha$, interferon $\gamma$ and tumour necrosis factor (TNF)- $\alpha$, and occurs in a variety of cells, including adipocytes [5-10], professional phagocytes [11,12], B-lymphocytes [13], vascular endothelia [14], fibroblasts [15], oocytes [16], thyrocytes [17], osteoclasts [18] and synaptosomes [19]. In addition, considerable progress is currently being made in identifying potential new targets for redox control. Examples of this type are metalloproteinases [20], fastinactivating $\mathrm{K}^{+}$channels in the brain [21], an endoplasmic tyrosine kinase of unknown function that is structurally related to the insulin receptor [22], translational activators, such as the iron-responsive-element-binding protein [23] and adenosineuridine-binding factor [24], as well as nuclear factors, including nuclear factor $\kappa \mathrm{B}$, and the products of the proto-oncogenes c-fos and c-jun [25-27]. Finally, most recently, evidence has been presented to suggest that the increase in protein phosphorylation seen in the presence of TNF- $\alpha$ may be mediated via inhibition of a redox-sensitive phosphatase [28].

Together, the findings summarized above strongly argue for an involvement of redox processes in signalling by hormones and cytokines. However, the mechanisms whereby ligand binding to cell-surface receptors may result in a change in the intracellular redox equilibrium have remained obscure. We have previously shown that human fat-cells possess an insulin-sensitive $\mathrm{H}_{2} \mathrm{O}_{2}$ generating system that remains responsive to receptor-mediated activation in cell-free preparations [5]. Here we demonstrate that this system is coupled to multiple receptors mediating antagonistic effects of a large and diverse group of hormones and cytokines, and hence meets the criteria of a universal signaltransducing system for hormones and cytokines.

\section{MATERIALS AND METHODS}

Experimental procedures have been described in detail elsewhere [5]. Briefly, adipose tissue was from non-diabetic subjects undergoing elective abdominal or cosmetic breast surgery. The tissue specimens were cut into small pieces and fat-cells were isolated by the method of Rodbell [29] in Hepes-buffered Krebs-Henseleit solution, pH 7.4, containing $20 \mathrm{mM}$ Hepes, $5 \mathrm{mM}$ glucose, $20 \mathrm{~g} / 1$ human albumin and $1 \mathrm{mg} / \mathrm{ml}$ collagenase. After $30 \mathrm{~min}$, fat-cells were washed and resuspended in the same buffer, except that collagenase was omitted.

\section{Receptor-mediated modulation of NADPH-dependent $\mathrm{H}_{2} \mathrm{O}_{2}$ production}

To assess the regulatory effects of hormones and cytokines in intact cells, packed adipocytes were exposed to various con- 
centrations of ligands for $10 \mathrm{~min}$ at $37^{\circ} \mathrm{C}$. Thereafter, the cells were resuspended in $10 \mathrm{vol}$. of an ice-cold lysing medium containing $20 \mathrm{mM}$ Mes, $\mathrm{pH} \mathrm{5.8,2 \textrm {mM } \mathrm { MgCl }}$, $1 \mathrm{mM} \mathrm{CaCl}$, $5 \mathrm{mM} \mathrm{KCl}$ and $100 \mathrm{mg} / 1$ soyabean trypsin inhibitor. Cell lysis was completed by mechanical shaking and fat-cell ghosts were collected by low-speed centrifugation $\left(1000 \mathrm{~g} ; 4^{\circ} \mathrm{C} ; 20 \mathrm{~min}\right)$.

To investigate the effects of ligands in cell-free preparations, ghosts were first exposed to $\mathrm{Mn}^{2+}$ and ligands $\left(25^{\circ} \mathrm{C} ; 30 \mathrm{~min}\right)$, then thoroughly washed and assayed for NADPH oxidase activity. Preincubations were carried out in $30 \mathrm{mM}$ Mops, $\mathrm{pH}$ 7.5 , containing $120 \mathrm{mM} \mathrm{NaCl}, 1.4 \mathrm{mM} \mathrm{CaCl}_{2}$ and $0.1 \%$ human albumin. Initially, $\mathrm{MnCl}_{2}(3 \mathrm{mM})$ was present from the start of the preincubations. Later in the course of investigations, membranes were first incubated with the various ligands for $5 \mathrm{~min}$ to allow the formation of ligand-receptor complexes. Thereafter $\mathrm{MnCl}_{2}(3 \mathrm{mM})$ was added and preincubations were continued for another $20 \mathrm{~min}$. After $25 \mathrm{~min}$, ghosts were collected by centrifugation, washed and resuspended in $30 \mathrm{mM}$ Mes, $\mathrm{pH} 5.8$, containing $120 \mathrm{mM} \mathrm{NaCl}, 4 \mathrm{mM} \mathrm{MgCl}, 1.2 \mathrm{mM} \mathrm{K \textrm {K } _ { 2 }} \mathrm{PO}_{4}$, $1 \mathrm{mM} \mathrm{NaN}_{3}$ and $10 \mu \mathrm{M}$ FAD.

\section{Assay of NADPH-dependent $\mathrm{H}_{2} \mathrm{O}_{2}$ generation}

Proportional increases in NADPH-dependent $\mathrm{H}_{2} \mathrm{O}_{2}$ production were limited to a narrow range of protein concentrations,. Therefore assays were routinely performed at four different protein concentrations ranging from 2 to $20 \mu \mathrm{g} / \mathrm{ml}$. Reactions were started by addition of $0.25 \mathrm{mM} \mathrm{NADPH}$, and were terminated after $30 \mathrm{~min}$ at $37^{\circ} \mathrm{C}$ by adding $\mathrm{HCl}\left(\mathrm{H}_{2} \mathrm{O}_{2}\right.$ determinations) or $\mathrm{KOH}$ (NADPH measurements) to yield final concentrations of $0.1 \mathrm{mM}$.

After the reaction had been stopped, the samples were extensively diluted (30-1000 times) and assayed for $\mathrm{H}_{2} \mathrm{O}_{2}$ using oxidation of luminol in the presence of peroxidase as the indicator reaction [30]. The assays mixtures contained $0.1 \mathrm{M} \mathrm{Na}_{2} \mathrm{PO}_{4}, \mathrm{pH}$ 8.2, $0.72 \mathrm{~g} / 1$ EDTA, $12.5 \mu \mathrm{M}$ luminol and $0.1 \mathrm{~m}$-unit $/ \mathrm{ml}$ horseradish peroxidase in a total volume of $0.2 \mathrm{ml}$. Reactions were carried out in the absence or presence of $0.1 \mathrm{unit} / \mathrm{ml}$ catalase (thymol-free) to account for non-specific reactions. External standards $\left(10-100 \mathrm{nM} \mathrm{H}_{2} \mathrm{O}_{2}\right)$ contained all components that were present in the samples, except that membranes were omitted. Light output was stable for $20 \mathrm{~s}$ and the integral of counts between 5 and $10 \mathrm{~s}$ was taken as a measure of $\mathrm{H}_{2} \mathrm{O}_{2}$ concentration. The detection limit for $\mathrm{H}_{2} \mathrm{O}_{2}$ was in the range 5-10 nM, and light output was linearly related to $\mathrm{H}_{2} \mathrm{O}_{2}$ concentration up to $100 \mathrm{nM}$. NADPH was measured by using bacterial NAD(P)H-linked luciferase [31]. Protein concentrations were determined by the method of Lowry et al. [32].

\section{Chemicals}

Human serum albumin, luminol and catalase (thymol-free) were from Behring Werke (Marburg, Germany), Fluka AG (Basel, Switzerland) and Sigma G.m.b.H. (München, Germany). The buffer components Mes, Mops and Hepes were from Serva G.m.b.H. (Heidelberg, Germany). Recombinant human TNF- $\alpha$, oxytocin, bovine insulin and the majority of enzymes and coenzymes were from Boehringer-Mannheim (Mannheim, Germany). Recombinant human acidic and basic fibroblast growth factor (aFGF and bFGF), (-)-isoprenaline and propranolol were from Sigma. The monoclonal antibodies directed against the $75 \mathrm{kDa}$ (htr-9) and the $55 \mathrm{kDa}$ (utr-1) receptors for TNF- $\alpha$ were a gift from Dr. M. Brockhaus, Hoffman-La Roche AG (Basel, Switzerland). Platelet-derived growth factor (PDGF) AA and BB were kindly donated by Dr. J. Hoppe, Institut für
Physiologische Chemie, Universität Würzburg, Germany. $\left[\mathrm{d}\left(\mathrm{CH}_{2}\right)_{5}, \mathrm{D}-\mathrm{Tyr}(\mathrm{Et})^{2}, \mathrm{Val}^{4}, \mathrm{Cit}^{8}\right]$ vasopressin was from Peninsula Laboratories G.m.b.H. (Heidelberg, Germany).

\section{RESULTS}

Previous studies showed that $\mathrm{Mn}^{2+}$ was the sole cofactor required for insulin-induced activation of NADPH-dependent $\mathrm{H}_{2} \mathrm{O}_{2}$ generation in crude human fat-cell plasma membranes in vitro [5]. These same conditions were also sufficient to elicit the regulatory effects of all hormones and cytokines tested in the current studies. $\mathrm{Mn}^{2+}$ is well known to participate catalytically in redox chemistry [12]. Therefore, the bivalent cation was removed by extensive washing before measurement of NADPH oxidative activity. To ensure that the results were in fact related to the action of hormones and cytokines, rather than reflecting in vitro artifacts produced by $\mathrm{Mn}^{2+}$, we took advantage of the fact that the regulatory effects of the agents tested could be elicited in intact cells in the absence of $\mathrm{Mn}^{2+}$ [5]. Table 1 shows the effects of maximal concentrations of insulin, oxytocin and isoprenaline when applied to intact cells in the absence of $\mathrm{Mn}^{2+}$ or to crude plasma membranes in its presence. Insulin and oxytocin caused a twofold increase in $\mathrm{H}_{2} \mathrm{O}_{2}$ production under both conditions. In contrast, pretreatment of adipocytes or plasma membranes with $1 \mu \mathrm{M}$ isoprenaline resulted in a decrease in NADPH-dependent $\mathrm{H}_{2} \mathrm{O}_{2}$ generation by nearly half in either condition. No additive effects occurred when the system was first activated in intact cells and was then exposed to $\mathrm{Mn}^{2+}$ and ligands in vitro or when cells or membranes were incubated in the simultaneous presence of maximal concentrations of insulin and oxytocin (Table 1). Isoprenaline consistently inhibited $\mathrm{H}_{2} \mathrm{O}_{2}$ generation to a comparable extent under both conditions.

Despite their stability, the regulatory effects of insulin, oxytocin and isoprenaline were reversible. When membranes from cells that had been pretreated with isoprenaline were exposed to stimulatory ligands in vitro, the inhibitory effect of isoprenaline was reversed, and the rate of NADPH-dependent $\mathrm{H}_{2} \mathrm{O}_{2}$ generation was virtually identical with that seen in the presence of insulin or oxytocin alone (Table 1). Likewise, when membranes from cells that had been pretreated with insulin or oxytocin were exposed to isoprenaline in vitro, their stimulatory effects were completely reversed (Table 1$)$.

Table 1 Effect of maximal concentrations of insulin, oxytocin and isoprenaline on $\mathrm{NADPH}-d e p e n d e n t \mathrm{H}_{2} \mathrm{O}_{2}$ generation in crude plasma membranes from untreated cells and adipocytes pretreated with insulin or isoprenaline respectively

Intact adipocytes were preincubated in the absence or presence of $1 \mu \mathrm{M}$ isoprenaline or $10 \mathrm{nM}$ insulin. Thereafter, the cells were lysed, and fat-cell ghosts were exposed to insulin, oxytocin or isoprenaline as indicated. Experimental details are given in the Materials and methods section. Values are means \pm S.E.M. of nine separate experiments for each condition. Values significantly different from untreated cells without additions are indicated as follows: ${ }^{\star} P \leqslant 0.002 ;{ }^{\star \star} P \leqslant 0.001 ;{ }^{\star \star \star} P \leqslant 0.0001$ (Student's $t$ test).

\begin{tabular}{|c|c|c|c|}
\hline \multirow[b]{2}{*}{ Additions } & \multicolumn{3}{|c|}{$\mathrm{H}_{2} \mathrm{O}_{2}$ generation ( $\mathrm{nmol} / \mathrm{min}$ per $\mathrm{mg}$ ) } \\
\hline & $\begin{array}{l}\text { Untreated } \\
\text { cells }\end{array}$ & $\begin{array}{l}\text { Insulin-treated } \\
\text { cells }\end{array}$ & $\begin{array}{l}\text { Isoprenaline- } \\
\text { treated cells }\end{array}$ \\
\hline None & $42 \pm 10$ & $64 \pm 9^{\star \star \star}$ & $25 \pm 9^{\star \star}$ \\
\hline Insulin (5 nM) & $68 \pm 10^{\star \star \star}$ & $64 \pm 5^{\star \star}$ & $67 \pm 5^{\star \star \star}$ \\
\hline Oxytocin (10 nM) & $58 \pm 9^{*}$ & $63 \pm 7^{\star}$ & $61 \pm 9^{\star \star}$ \\
\hline Insulin + oxytocin & $68 \pm 2^{\star \star \star}$ & - & - \\
\hline Isoprenaline $(0.1 \mu \mathrm{M})$ & $26 \pm 4^{\star \star}$ & $40 \pm 8^{\star \star}$ & $25 \pm 9^{\star \star \star}$ \\
\hline
\end{tabular}




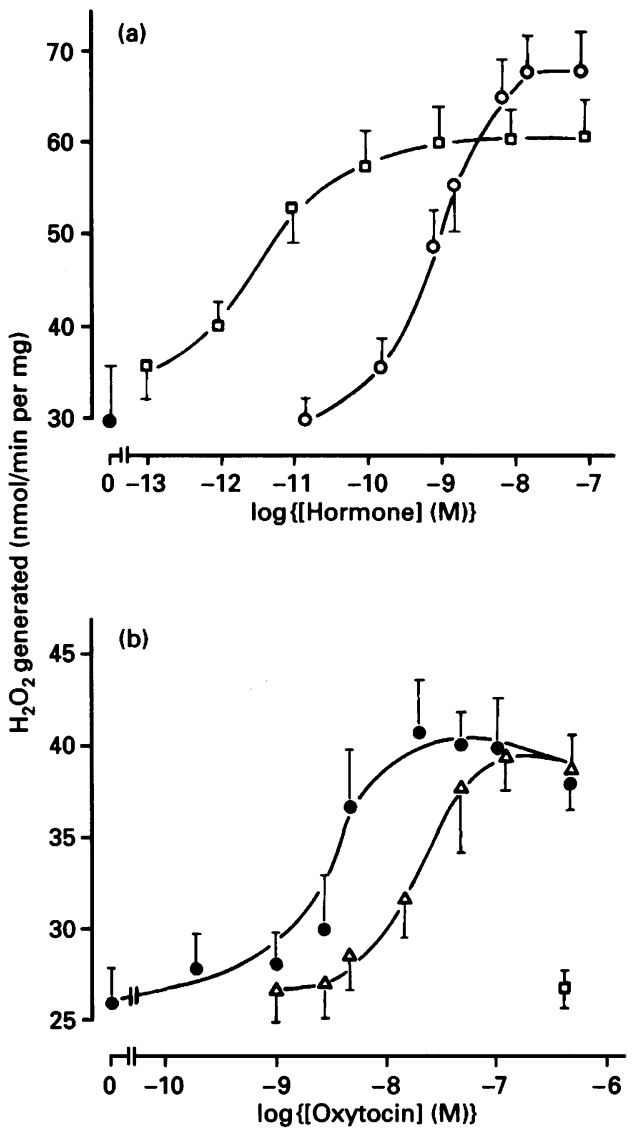

Figure 1 Concentration-response relationships for insulin, TNF- $\alpha$ and oxytocin: compettive inhibition of oxytocin action by a synthetic antagonist

(a) Crude plasma membranes were first exposed to increasing concentrations of insulin ( $\square$ ) or TNF- $\alpha(O)$ for $5 \mathrm{~min}$. Thereafter, $3 \mathrm{mM} \mathrm{MnCl}$ was added, and preincubations were continued for another $20 \mathrm{~min}$. After $25 \mathrm{~min}$, membranes were washed and assayed for NADPHdependent $\mathrm{H}_{2} \mathrm{O}_{2}$ generation. Values are means \pm S.E.M. of three experiments for each condition. (b) Crude plasma membranes were first exposed to various concentrations of oxytocin in the absence $(-)$ or presence $(\triangle)$ of $50 \mu \mathrm{M}$ of $\left[\mathrm{d}\left(\mathrm{CH}_{2}\right)_{5}, 0-\mathrm{Tyr}(\mathrm{Et})^{2}\right.$, Val ${ }^{4}$, $\left.\mathrm{Cit}^{8}\right]$ vasopressin, and were then assayed for NADPH-dependent $\mathrm{H}_{2} \mathrm{O}_{2}$ generation as described above. Values are means \pm S.E.M. of three separate experiments.

Figure 1 shows the effects of increasing concentrations of insulin, TNF- $\alpha$ (Figure 1a) and oxytocin (Figure 1b). These agents caused a concentration-dependent increase in NADPHdependent $\mathrm{H}_{2} \mathrm{O}_{2}$ generation and their maximal effects were comparable. Previous studies showed that the concentrations of insulin required to activate NADPH-dependent $\mathrm{H}_{2} \mathrm{O}_{2}$ generation in crude plasma membranes in vitro were more than two orders of the magnitude higher than those that were equieffective when intact cells were exposed to the hormone in vivo [5]. At acidic $\mathrm{pH}$, $\mathrm{Mn}^{2+}$ may catalyse a non-enzymic oxidation of NADPH and other molecules, including receptors and ligands [12]. Therefore conditions were introduced in the course of the present studies that allowed for pre-equilibration of binding before the addition of $\mathrm{Mn}^{2+}$ as described in the Materials and methods section. Using this modification of assay conditions, the sensitivity to insulin was markedly improved. Half-maximal activation of NADPH-dependent $\mathrm{H}_{2} \mathrm{O}_{2}$ generation occurred at approx. $3 \mathrm{pM}$ insulin under these conditions, a value that corresponds closely to those published for the antilipolytic potency of insulin in human fat-cells or activation of pyruvate dehydrogenase in
Table 2 Modulation of TNF- $\alpha$ action by receptor subtype-specific monoclonal antibodies

Crude plasma membranes were exposed to antibodies htr-9 (agonist at the $55 \mathrm{kDa}$ receptor for TNF) or utr-1 (TNF antagonist at the $75 \mathrm{kDa}$ receptor) in PBS containing $1 \mathrm{mg} / \mathrm{ml}$ albumin and $30 \mu \mathrm{g} / \mathrm{ml}$ antibody for $30 \mathrm{~min}$ at $37^{\circ} \mathrm{C}$. Membranes were washed, incubated in the absence or presence of $10 \mathrm{nM}$ TNF- $\alpha$, and were assayed for NADPH-dependent $\mathrm{H}_{2} \mathrm{O}_{2}$ generation as described in the Materials and methods section and the legend to Figure 1. Values are means \pm S.E.M. of six separate experiments. ${ }^{*} P \leqslant 0.001$ (Student's $t$ test for paired observations).

\begin{tabular}{llll}
\hline & \multicolumn{2}{l}{$\mathrm{H}_{2} \mathrm{O}_{2}$ generation (nmol/min per $\left.\mathrm{mg}\right)$} \\
\cline { 2 - 4 } Additions & Untreated cells & utr-1-treated cells & htr-9-treated cells \\
\hline None & $28 \pm 2$ & $28 \pm 3$ & $33 \pm 2$ \\
TNF- $\alpha$ & $46 \pm 6$ & $29 \pm 5^{\star}$ & $48 \pm 7$ \\
\hline
\end{tabular}

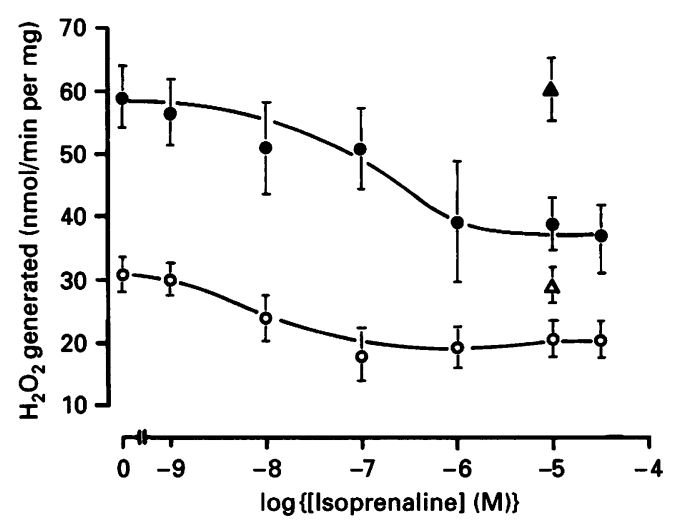

Figure 2 Concentration-activity profile for isoprenaline in the absence or presence of insulin

Crude plasma membranes were preincubated with increasing concentrations of isoprenaline in the absence $(\mathrm{O})$ or presence $(O)$ of $5 \mathrm{nM}$ insulin or incubated with $10 \mu \mathrm{M}$ isoprenaline and $100 \mu \mathrm{M}$ propranolol in the absence $(\Delta)$ or presence $(\Delta)$ of $5 \mathrm{nM}$ insulin, and were then assayed for NADPH-dependent $\mathrm{H}_{2} \mathrm{O}_{2}$ generation, as described in the Materials and methods section. Values are means \pm S.E.M. of six experiments for each condition.

Chinese hamster ovary cells $[33,34]$. TNF- $\alpha$ was 300 times less active than insulin.

Figure 1(b) shows dose-response curves for oxytocin in the absence or presence of $50 \mu \mathrm{M}\left[\mathrm{d}\left(\mathrm{CH}_{2}\right)_{5}, \mathrm{D}-\mathrm{Tyr}(\mathrm{Et})^{2}, \mathrm{Val}^{4}, \mathrm{Cit}^{8}\right]$ vasopressin, a potent antagonist at oxytocin/vasopressin receptors [35]. Oxytocin was approximately as potent as TNF- $\alpha$ in stimulating NADPH-dependent $\mathrm{H}_{2} \mathrm{O}_{2}$ generation. At the concentration used $(50 \mu \mathrm{M})$, the inhibitor caused a 10 -fold rightward shift of the dose-response curve for oxytocin, whereas insulin action was not influenced at all. Similarly, the stimulatory effects of TNF- $\alpha$ could be blocked specifically by a monoclonal antibody directed against the $75 \mathrm{kDa}$ receptor for TNF- $\alpha$ (utr-1) (Table 2). Another antibody, htr-9, which mimics some of the effects of TNF- $\alpha$ mediated via the $55 \mathrm{kDa}$ receptor [36-38], did not influence the stimulatory effect of TNF- $\alpha$ on NADPHdependent $\mathrm{H}_{2} \mathrm{O}_{2}$ generation and had no effect on its own.

Figure 2 shows the effects of various concentrations of isoprenaline on basal and ligand-activated rates of NADPHdependent $\mathrm{H}_{2} \mathrm{O}_{2}$ generation. Isoprenaline inhibited $\mathrm{H}_{2} \mathrm{O}_{2}$ pro- 


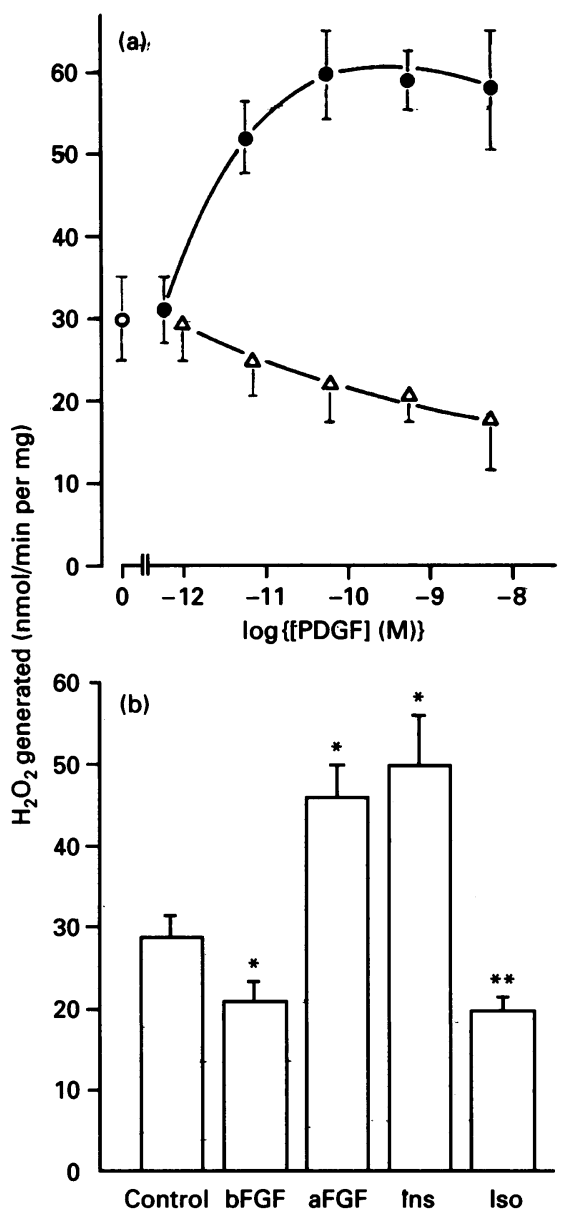

Figure 3 Antagonistic effects of the different members of the PDGF and FGF familles on NADPH-dependent $\mathrm{H}_{2} \mathrm{O}_{2}$ generation

(a) Crude plasma membranes from untreated adipocytes were first exposed to increasing concentrations of PDGF AA $(\Theta)$ or PDGF BB $(\triangle)$, and were then assayed for NADPHdependent $\mathrm{H}_{2} \mathrm{O}_{2}$ generation, as described. Values are means \pm S.E.M. of six experiments for each condition. (b) Membranes were preincubated in the absence or presence of $5 \mathrm{nM}$ insulin (Ins), $0.1 \mu \mathrm{M}$ isoprenaline (Iso) and $0.25 \mathrm{nM}$ aFGF or bFGF, and were then assayed for NADPH-dependent $\mathrm{H}_{2} \mathrm{O}_{2}$ generation as described. Values are means \pm S.E.M. of four separate experiments for each condition. Values significantly different from controls are indicated as follows: ${ }^{*} P \leqslant 0.001 ;{ }^{* \star} P \leqslant 0.004$ (Student's $t$ test for paired observations).

duction under both conditions, and the inhibitory effect was dose-dependent. A half-maximal inhibition of basal activity occurred at $10 \mathrm{nM}$ isoprenaline, whereas $0.1 \mu \mathrm{M}$ was required to produce a comparable effect in the presence of $10 \mathrm{mM}$ insulin. The isoprenaline-induced inhibition of NADPH-dependent $\mathrm{H}_{2} \mathrm{O}_{2}$ generation was prevented by the non-selective $\beta$-adrenergic receptor antagonist propanolol, which, on itself, had no effects on basal activity or ligand-activated rates of $\mathrm{H}_{2} \mathrm{O}_{2}$ generation (Figure 2). The $\alpha$-adrenergic receptor antagonists prazosin $\left(\alpha_{1}\right)$ and yohimbine $\left(\alpha_{2}\right)$ failed to reverse the isoprenaline-induced suppression of NADPH-dependent $\mathrm{H}_{2} \mathrm{O}_{2}$ generation when tested at concentrations ranging from 0.1 to $50 \mu \mathrm{M}$ (results not shown). Taken together, these data indicate that the inhibition of NADPH-dependent $\mathrm{H}_{2} \mathrm{O}_{2}$ generation by isoprenaline was mediated via a $\beta$-adrenergic receptor.

Isoprenaline was not the sole inhibitor. At least two other ligands, e.g. PDGF BB and bFGF, potently suppressed NADPHdependent $\mathrm{H}_{2} \mathrm{O}_{2}$ generation. This is illustrated in Figure 3 which shows the effects of different members of the FGF and PDGF families on NADPH-dependent $\mathrm{H}_{2} \mathrm{O}_{2}$ generation in crude plasma membranes. The inhibitory actions of PDGF BB and bFGF were apparent at picomolar concentrations, and the extent of inhibition was comparable with that seen in the presence of isoprenaline. Interestingly, the inhibitory effects of PDGF BB and bFGF were isoform-specific. PDGF AA and aFGF had opposite effects. These latter members of the PDGF and FGF families caused a twofold increase in NADPH-dependent $\mathrm{H}_{2} \mathrm{O}_{2}$ generation that showed dose-dependence; half-maximal activation occurred at approx. 3 pM PDGF AA and 5 pM aFGF respectively.

\section{DISCUSSION}

In a previous study [5] it was shown that human fat-cells possess a plasma-membrane-bound $\mathrm{H}_{2} \mathrm{O}_{2}$-generating system that is activated by insulin. This work demonstrates that insulin is only one example of a large and diverse group of hormones and cytokines exerting stimulatory and inhibitory effects on NADPHdependent $\mathrm{H}_{2} \mathrm{O}_{2}$ generation in human fat-cell plasma membranes. Insulin and oxytocin stimulated NADPH-dependent $\mathrm{H}_{2} \mathrm{O}_{2}$ generation, whereas isoprenaline had inhibitory effects, consistent with early reports showing analogous effects of these same agents on formate oxidation (which is thought to reflect $\mathrm{H}_{2} \mathrm{O}_{2}$ production) in intact adipocytes [6-9].

TNF- $\alpha$ had a wide variety of biological activities depending on the cell type and the growth state of cells, including cytotoxicity and modulation of cell growth and differentiation [39]. In L929 fibrosarcoma cells the cytotoxic effects seem to involve an enhanced mitochondrial production of reactive oxygen species at the ubisemiquinone site of the respiratory chain [40]. The present findings show that TNF- $\alpha$ stimulates a plasma-membrane-bound redox activity in human adipocytes, which are resistant to the cytotoxic action of the cytokine $[41,42]$. Thus it is possible that TNF- $\alpha$ can activate different redox activities that reside in distinct cellular compartments and may be involved in mediating different aspects of TNF action.

Even though multiple receptors exist for FGF and PDGF that display partial isoform specificity and may mediate distinct signals [43-46], the biological effects of different members of the FGF and PDGF families are remarkably similar [43,44]. It was therefore unexpected that the acidic and basic isoforms of FGF as well as the AA and BB homodimers of PDGF had antagonistic effects on $\mathrm{H}_{2} \mathrm{O}_{2}$ generation in human fat-cell ghosts. As discussed below these unexpected results prompted the search for the isoform-specific cellular responses which revealed that the antagonistic effects of these FGF and PDGF isoforms on NADPHdependent $\mathrm{H}_{2} \mathrm{O}_{2}$ generation are paralleled by corresponding effects on adipose conversion in 3T3 L1-cells [47].

The effects of all ligands occurred at concentrations that are physiologically relevant. In addition, the effects of isoprenaline, oxytocin and TNF could be overcome by selective receptor antagonists (isoprenaline, oxytocin) or receptor antibodies (TNF) respectively. Along with the observation that maximally effective concentrations of stimulatory ligands had no additive effects, the findings summarized above strongly support the view that all ligands acted at discrete ligand-specific receptors converging to a common $\mathrm{H}_{2} \mathrm{O}_{2}$-generating system.

This is surprising because the receptors are members of distinct receptor families thought to be coupled to different mechanisms of signal transduction. The receptors for insulin, PDGFs and FGFs are membrane-spanning tyrosine kinases [43-46]. The $\beta$ adrenergic receptor and the receptor for oxytocin belong to the 
superfamily of heptahelical receptors, and are thought to transmit their signals via interaction with heterotrimeric guanine nucleotide regulatory proteins $[48,49]$. To date, two immunologically distinct receptors for TNF of approx. $55 \mathrm{kDa}$ and $75 \mathrm{kDa}$ have been cloned [36-38]. Neither bears any resemblance to tyrosine kinases or to the intracellular sequence of other receptors; the mechanisms by which the receptors for TNF- $\alpha$ transmit signals remain to be determined [50].

Similarly to a growth factor-responsive NADH oxidase that is present in plant and liver cells [51], the mechanisms by which hormones and cytokines regulate NADPH-dependent $\mathrm{H}_{2} \mathrm{O}_{2}$ production are membrane-delimited, independent of second messengers, and operate in the absence of ATP, indicating that established pathways of signal transduction, including the tyrosine kinase activities of the receptors for insulin, PDGF and FGF or second-messenger-dependent protein kinases A and C, are not involved. These findings place the human fat-cell oxidase in a position comparable with adenylate cyclase and suggest a physical interaction between receptors and NADPH oxidase, or receptor-effector coupling via (a) signal-transducing protein(s).

Intriguingly, the regulatory effects of all ligands tested were dependent on millimolar concentrations of $\mathrm{Mn}^{2+}$ ions. Supraphysiological concentrations of $\mathrm{Mn}^{2+}$ are also required for a ligand-induced activation of receptor protein-tyrosine kinases in cell-free preparations [52]. As the concentrations of $\mathrm{Mn}^{2+}$ required to achieve a ligand-induced activation of receptor protein-tyrosine kinases (and of NADPH-dependent $\mathrm{H}_{2} \mathrm{O}_{2}$ generation) exceed its intracellular concentrations by orders of magnitude, it has been proposed that $\mathrm{Mn}^{2+}$ may mimic an unknown factor that is present in intact cells [52]. Indeed, $\mathrm{Mn}^{2+}$, which is active at millimolar concentrations only, could be replaced by micromolar concentrations of the stable guanine nucleotide analogue, guanosine $5^{\prime}-[\gamma$-thio $]$ triphosphate, suggesting that the bivalent cation mimics some of the effects of GTP (H. I. Krieger-Brauer and H. Kather, unpublished work). These findings are in accord with previous reports suggesting that the stimulatory effect of $\mathrm{Mn}^{2+}$ on adenylate cyclase may involve a change in G-protein function [53,54] and may explain why similar $\mathrm{Mn}^{2+}$ concentrations were required for all ligands tested.

As pointed out in the Introduction, redox control appears to be a broad regulatory system that could allow cells to adapt to environmental changes and appears also to be involved in signalling by hormones and cytokines [4]. A major question that has remained unanswered is how is the binding of ligands to cellsurface receptors translated into changes in intracellular redox state? The present studies demonstrate that the stimulus-sensitive $\mathrm{H}_{2} \mathrm{O}_{2}$-generating system that is present in human fat-cell plasma membranes meets all criteria of a universal effector system for hormones and cytokines, and thus may provide the missing link between ligand binding to cell-surface receptor and changes in intracellular redox state. In being multireceptor-linked and bidirectionally regulated, this plasma membrane-bound redox activity appears to be as versatile as other general signaltransducing systems, such as adenylate cyclase or $\mathrm{Na}^{+} / \mathrm{H}^{+}$ exchange, suggesting a fundamental role in normal fat-cell physiology.

Intact cells contain iron-containing compounds and other redox-active molecules, such as thioredoxin [55], which could serve as natural acceptors of electrons from NADPH instead of oxygen in vivo. However, the ligands that stimulated $\mathrm{H}_{2} \mathrm{O}_{2}$ generation in crude plasma membranes also stimulated the production of $\mathrm{H}_{2} \mathrm{O}_{2}$ in intact cells, whereas inhibitors of the $\mathrm{H}_{2} \mathrm{O}_{2}$-generating system, such as isoprenaline or bFGF, also inhibited $\mathrm{H}_{2} \mathrm{O}_{2}$ accumulation in intact cells [9]. Even though it cannot definitely be excluded that the mechanisms whereby hormones and cytokines modulate $\mathrm{H}_{2} \mathrm{O}_{2}$ generation in crude plasma membranes are different from those that are operative in intact cells, this marked parallelism is probably more than coincidental and suggests that oxygen is the natural electron acceptor in intact cells.

As pointed out previously [5] and summarized in the Introduction, $\mathrm{H}_{2} \mathrm{O}_{2}$ qualifies for a second-messenger function. However, the role assumed by $\mathrm{H}_{2} \mathrm{O}_{2}$ in the propagation of hormone and cytokine signals as well as the regulatory functions of cytokines in mature fat-cells remain to be defined. The acidic and basic isoforms of FGF as well as homodimeric PDGF AA and BB also have antagonistic effects on NADPH-dependent $\mathrm{H}_{2} \mathrm{O}_{2}$ generation in 3T3 L1-preadipocytes. In these cells bFGF and PDGF BB, which suppress $\mathrm{H}_{2} \mathrm{O}_{2}$ generation, have antiadipogenic effects, whereas aFGF and PDGF AA, which stimulate $\mathrm{H}_{2} \mathrm{O}_{2}$ production, accelerate adipose conversion. These effects can be mimicked by exogenous hypoxanthine/xanthine oxidase or addition of antioxidants respectively, suggesting that the $\mathrm{H}_{2} \mathrm{O}_{2}$ produced in response to hormones and cytokines may be important in the regulation of fat-cell differentiation and maintenance of the differentiated state.

We are indebted to B. Sattel and B. Gail for expert technical assistance, and thank Dr. M. Brockhaus (Hoffmann-La Roche AG, Basel, Switzerland) for supplying antibodies against TNF receptors, and Dr. J. Hoppe (Universität Würzburg, Germany) for supplying PDGF AA. This work was supported by a grant from the Bundesministerium für Forschung und Technologie, Bonn, Germany.

\section{REFERENCES}

1 Halliwell, B. and Gutteridge, J. M. C. (1984) Biochem. J. 219, 1-14

2 Ikebuchi, Y., Masumoto, N., Tasaka, K. et al. (1991) J. Biol. Chem. 266, 13233-13237

3 Ramasarma, T. (1982) Biochim. Biophys. Acta 694, 69-93

4 Devary, Y., Gottlieb, R. A., Smeal, T. and Karin, M. (1992) Cell 71, 1081-1091

5 Krieger-Bauer, H. I. and Kather, H. (1992) J. Clin. Invest. 89, 1006-1013

6 Mukherjee, S. P. and Lynn, W. S. (1977) Arch. Biochem. Biophys. 184, 69-76

7 Mukherjee, S. P. (1980) Biochem. Pharmacol. 29, 1239-1246

8 Mukherjee, S. P. and Mukherjee, C. (1982) Arch. Biochem. Biophys. 214, 211-222

9 Muchmore, D. B., Little, S. A. and deHaen, C. (1982) Biochemistry 21, 3886-3892

10 Kadota, S., Fantus, I. G., Deragon, G., Guyda, H. J. and Posner, B. (1987) J. Biol. Chem. 262, 8252-8256

11 Rossi, F. (1986) Biochim. Biophys. Acta 853, 65-89

12 Hurst, J. K. and Barrett, Jr., W. C. (1989) Crit. Rev. Biochem. 24, 271-328

13 Maly, F. E., Cross, A. R., Jones, 0. T. G. et al. (1988) J. Immunol. 140, 2334-2339

14 Matsubara, T. and Ziff, M. (1986) J. Immunol. 137, 3295-3298

15 Meier, B., Radeke, H. H., Selle, S., Young, M., Sies, H., Resch, K. and Habermehl, G. G. (1989) Biochem. J. 263, 539-545

16 Heinecke, J. W. and Shapiro, B. M. (1989) Proc. Natl. Acad. Sci. U.S.A. 86, 1259-1263

17 Deme, D., Virion, A., Hammon, N. A. and Pommier, J. (1985) FEBS Lett. 186 107-110

18 Garrett, J. R., Boyce, B. F., Oreffo, R. O. F., Bonewald, L., Poser, J. and Mundy, G. R. (1990) J. Clin. Invest. 85, 632-639

19 Zoccarato, F., Deana, R., Cavallini, L. and Alexandre, A. (1989) Eur. J. Biochem. 180 $473-478$

20 Desrochers, P. E., Mookthiar, K., van Wart, H. E., Hasty, K. A. and Weiss, S. J. (1992) J. Biol. Chem. 267, 5005-5012

21 Ruppersberg, P., Stocker, M., Pongs, 0., Heinemann, S. H., Frank, R. and Konenen, M. (1991) Nature (London) 352, 711-714

22 Bauskin, A. R., Alkalay, I. and Ben-Neriah, Y. (1991) Cell 66, 685-696

23 Hentze, M. W., Rouault, T. A., Harford, J. B. and Klausner, R. D. (1989) Science 244 357-359

24 Malter, J. S. and Hong, Y. (1991) J. Biol. Chem. 266, 3167-3171

25 Staal, F. J. T., Roederer, M., Herzenberg, L. A. and Herzenberg, L. A. (1990) Proc. Natl. Acad. Sci. U.S.A. 87, 9943-9947

26 Schreck, R., Rieber, P. and Baeuerle, A. (1991) EMB0 J. 10, 2247-2258

27 Abate, C., Patel, L., Rauscher III, F. J. and Curran, T. (1990) Science 249, 1157-1161

28 Guy, G. R., Cairns, J., Ng, S. B. and Tang, Y. H. (1993) J. Biol. Chem. 268, 2141-2148 
29 Rodbell, M. (1964) J. Biol. Chem. 239, 375-384

30 Kather, H., Wieland, E. and Waas, W. (1987) Anal. Biochem. 163, 45-51

31 Kather, H. and Wieland, E. (1984) Methods Enzym. Anal. (3rd Ed.) 6, 510-518

32 Lowry, O. H., Rosebrough, N. J., Farr, A. L. and Randall, R. J. (1951) J. Biol. Chem. 193, 265-275

33 Kather, H., Wieland, E., Scheurer, A., Vogel, G., Wildenburg, U. and Joost, C. (1987) J. Clin. Invest. 80, 566-572

34 Gottschalk, W. K. (1991) J. Biol. Chem. 266, 8814-8819

35 Sawyer, W. H. and Manning, M. (1989) in Oxytocin (Amico, J. A. and Robinson, J. G., eds.), pp. 401-439, Elsevier, Amsterdam

36 Loetscher, H., Pan, Y.-C. E., Lahm, H.-W. et al. (1990) Cell 61, 351-359

37 Loetscher, H., Schlaeger, E. J., Lahm, H.-W., Pan, Y.-C. E., Lesslauer, W. and Brockhaus, M. (1990) J. Biol. Chem. 265, 20131-20138

38 Brockhaus, M., Schoenfeld, H.-J., Schlaeger, E. J., Hunziker, W., Lesslauer, W. and Loetscher, H. (1990) Proc. Natl. Acad. Sci. U.S.A. 87, 3127-3131

39 Camussi, G., Albano, E., Tetta, C. and Bussolino, F. (1991) Eur. J. Biochem. 202, 3-14

40 Schulte-Osthoff, K., Bakker, A. C., Vanhaesebroeck, B., Beyaert, R., Jacob, W. A. and Fliers, W. (1992) J. Biol. Chem. 267, 5317-5323

41 Kern, P. A. (1988) J. Lipid Res. 29, 909-914

42 Hotamisligil, G. S., Shargill, N. S. and Spiegelman, B. M. (1993) Science 259, 87-91
43 Ledoux, D., Gannoun-Zaki, L. and Barritault, D. (1993) Prog. Growth Factor Res. 4, $107-120$

44 Heldin, C.-H. (1992) EMBO J. 11, 4251-4259

45 Kondo, T. Konishi, F. Inui, H. and Inagami, T. (1993) J. Biol. Chem. 268 $4458-4464$

46 Koyama, N., Morisaki, N., Saito, Y. and Yoshida, S. (1992) J. Biol. Chem. 267, 22806-22812

47 Krieger-Brauer, H. I. and Kather, H. (1995) Biochem. J. 307, 549-556

48 Kimura, T., Tanizawa, O., Mori, K., Brownstein, M. J. and Okayama, H. (1992) Nature (London) 356, 526-529

49 Boege, F., Neumann E. and Helmreich, E. J. M. (1991) Eur. J. Biochem. 199, 1-15

50 Kim, M.-Y., Linardic, C., Obeid, L. and Hannun, Y. (1991) J. Biol. Chem. 266, 484-489

51 Bruno, M., Brightman, A. 0., Lawrence, J., Werderitsh, D., Morre, D. M. and Morre, D. J. (1992) Biochem. J. 284, 625-628

52 Wente, S. R., Villalba. M., Schramm, V. L. and Rosen, O. R. (1990) Proc. Natl. Acad. Sci. U.S.A. 87, 2805-2809

53 Houslay, M. D., Heyworth, C. M. and Whetton, A. D. (1983) FEBS Lett. 155, 311-316

54 Mattera, R., Codina, J., Sekura, R. D. and Birnbaumer, L. (1986) J. Biol. Chem. 261, 11173-11179

55 Holmgreen, A. (1989) J. Biol. Chem. 264, 13963-13966

Received 12 April 1994/21 November 1994; accepted 9 December 1994 